\title{
Enhancing students' active involvement, motivation and learning outcomes on mathematical problem using problem-based learning
}

\author{
Lisya Yulia Sari ${ }^{1}$, M.Fachri Adnan ${ }^{2}$, Hadiyanto $^{3}$ \\ ${ }^{1}$ Faculty of education Universitas Negeri Padang, Indonesia, $\$ lisyayuliasari90@gmail.com \\ ${ }^{2}$ Faculty of education Universitas Negeri Padang, Indonesia \\ ${ }^{3}$ Faculty of education Universitas Negeri Padang, Indonesia
}

\begin{abstract}
The rationale of this study was based on the problems experienced by the researcher especially in teaching mathematics. Students faced some difficulties in understanding and solving math problems especially the questions presented in stories; as a result, their learning outcomes were low. These difficulties were seen in the learning process in which the students were not active in learning. They were also ignorant, noisy and bored during a learning process. In the primary study, it has been predicted that this would happen due to the conventional way of teaching which is lecturing. Hence, the students' active involvement in the class was low, and they were less motivated in learning. Problem Based Learning (PBL) learning model is one solution that can be used to enhance students' active involvement, motivation and learning outcomes. This study was Classroom Action Research (CAR) which consisted of 2 cycles in which each cycle consisted of 2 meetings. Each cycle had three stages, namely the planning stage, the implementation and observation stages, and the reflection stage. At the observation stage, the researcher was assisted by observers who were observing and recording students' activity and learning motivation. In brief, the results revealed that after implementing of PBL model of learning, there was an improvement in students' activity, motivation and learning outcomes from one cycle to the next.
\end{abstract}

Keywords:: Problem Based Learning (PBL) model; active involvement, motivation, learning outcomes, math problem.

\section{Introduction}

Education plays a very important role in changing the future life of the nation, which is one of the determining factors to improve the quality of human resources. Education always strives for human life in the direction that is needed for life in the future. Furthermore, education plays a significant role in the framework of educating the lives of the nation. Therefore, the government implements a national education system that is oriented towards improving the quality of education.

Improving the quality of education is in line with the instructional objectives Kurikulum Tingkat Satuan Pendidikan (KTSP). This curriculum is based on character and competency that is to change the 
focus of education from orientation to results and material. Thus, learning must involve as many students as possible, so that they can explore their competencies, potentials, and scientific truths.

Based on the observation at grade V elementary school No 04 TiumangDharmasraya, it was found that in the learning process the teacher was not optimizing the students' understanding of KPK and FPB questions which were presented in the form story. The teacher simply led students to memorize concepts without asking them to understand the information contained in questions. Besides, the students were not required to be active, think critically, communicate, and use scientific thinking approaches. Teachers also often gave more short questions instead of problem-solving in form of story. Because of the teacher's habit of giving a short filling question, the students had difficulty in understanding the problem-solving story. When students faced difficulties in solving problem, the teacher ignored the problem, because the main point was that the students were able to memorize a concept. When they did, it means that the learning objectives have been achieved. As a result, when the students were confronted with the question presented in stories, they would not know how to solve the math problem and select appropriate methods to solve them. Then, they immediately solved it without understanding the information in the story, making the analysis, and having a clear picture in particular how to associate between the real conditions that they find every day with appropriate mathematical analysis.

Moreover, teachers rarely provided the opportunity for students to be active and involved during the learning process. Consequently, they seemed afraid when they were asked to answer the questions and given an opportunity to ask. The worst thing is that students were even less likely to know what to ask.This situation gave significant impact on students in which they tended to be less motivated in learning and their activities did not run optimally. In addition, conventional method of teaching which was implemented by the teacher led the students to feel bored and distracted, daydream, drowsy because it took long time to wait for friends to do the exercises or when they listened to the teacher explaining the material. In addition, the teacher still used conventional methods in the learning process, and the teacher only provided available questions in the textbook without linking it to the real life; thus, they were not attracted and motivated in learning.

Some methods have been tried to improve the learning process, such as by providing learning media, giving rewards stimulation, and giving individual or group assignments. However, the results obtained remained unsatisfactory and the scores were still under the Minimum Criteria. Due to this fact, the teacher plans to create an atmosphere of learning that can motivate students to always learn with full enthusiasm in order to master the concepts of science. Such learning atmosphere will have a positive impact to achieve optimal learning achievement. Therefore, teachers should have the ability to choose learning methods and make plans according to the needs of students.

In connection with the design of problem-based learning models, it is expected to make learning more motivating and the students will be encouraged to learn. In the learning process, the teacher needs to pay attention to the methods used, the assignments given according to the students' abilities, develop learning situations that allow each of them to work with each other and try to engage students in various learning activities. (Nuh, 2013)

Overcoming these problems, one learning model that is suitable for enhancing students' active involvement, motivation and student learning outcomes is Problem Based Learning (PBL) model. PBL is a learning model that uses problems as the first step in gathering and integrating new knowledge. This problem is used to link the curiosity and analytical abilities of students. PBL prepares students to think critically, and analytically to find and use appropriate learning resources (Amir, 2009). According to (Ronis, 2009) "PBL enables students to evolve into problem-solvers by honing the skills of reasoning, collaboration, and persistence". With PBL, it allows students to evolve into problem solvers by honing their reasoning, collaboration, and perseverance skills. 
PBL learning uses real-world problems as a context for students to learn critical thinking and problem-solving skills to gain new knowledge (Rusman, 2011). PBL can be defined as a series of learning activities that emphasize the process of solving problems faced scientifically, it has the main characteristics, namely: a series of learning activities in which PBL does not expect students to just listen, record, then memorize the subject matter, but through PBL students actively think, communicate, search, and process data, and finally conclude. The steps of the PBL model according to (Rusman, 2011) are as follows: "(1) student orientation to the problem, (2) leading students to learn, (3) guiding individual or group investigations, (4) developing and presenting the work, (5) analyzing and evaluating the problem-solving process.

The most important thing in the learning process is student learning activities. If there is not any activity that is done, it is impossible for someone to learn. Therefore, learning is not just memorizing a number of facts or information, but learning is an act of doing and gaining certain experiences in accordance with the expected goals. Effective learning activities are involving all students' abilities in using their senses. The more senses used, the more results of learning activities are obtained, or in other words the more activities carried out during learning, the more learning is carried out.

Based on the aforementioned explanation, it can be concluded that student activity is an activity carried out by students that can bring change in a better direction for students because of the interaction between individuals and individuals and individuals with the environment. By considering the learning model that is implemented, the types of activities that were observed were as follows: visual activity, oral activity, listening activity, writing activity, mental activity, and emotional activity. Activity indicators used were: (1) reading worksheets, (2) expressing opinions, (3) listening to opinions, (4) submitting reports, (5) answering worksheets, (6) solving problems, (7) interest, and (8) excitement.

The learning process also recognizes the existence of learning motivation in the form of motivation that is applied in learning activities. According to (Aunurrahman, 2009) "motivation in learning is a force that can encourage students to utilize the potential that exists in themselves and the potential outside themselves to realize learning goals. Furthermore, (Karwati \& Priansa, 2014) states that "learning motivation is behaviour and the factors that influence students to behave towards the learning process that they experience". Thus, learning motivation is a process that shows the intensity of students in achieving the direction and objectives of the learning process as they experience.

Basically, there are two types of motivation, namely intrinsic motivation and extrinsic motivation. Intrinsic motivation is called "pure motivation", or the actual motivation that arises from within the student without any influence from outside. While extrinsic motivation is motivation caused by factors from outside the learning situation, such as numbers, credit, diplomas, prize levels, medals, opposition and competition, and negative ones which are ridicule and punishment. (Hamalik, 2008)

PBL models can enhance students' learning outcomes in math because it can develop students' ability to think critically in order to transfer their knowledge in real life. PBL shows students that each subject is a way of thinking and not just learning from the teacher (Sanjaya, 2008).

\section{Method}

This study was a classroom action research. According to (Arikunto, 2009) classroom action research is "an observation of learning activities in the form of an action, which is deliberately raised and occurs in a class simultaneously". The research model used was the Kemmis and MC Taggart model.Kemmis and MC Taggart in (Arikunto, 2009) suggest that: "this cycle model has four main components namely planning, action, observation, and reflection".

\section{Chart 1. Classroom Action Research, Kemmis and MC Taggart model}




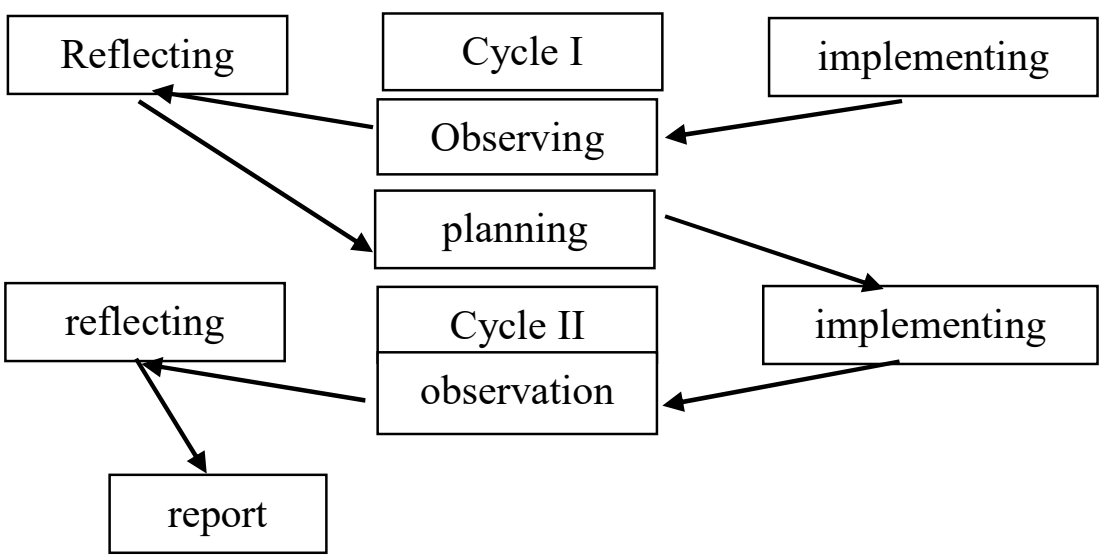

\section{Research Procedure}

1. Planning stage

Before carrying out the research, various initial preparations were done, namely:

a. Preparing lesson plan

b. Creating learning media

c. Preparing an assessment sheet

d. Discussing with observers about the learning process and explaining the observation sheet instructions.

2. Implementation stage

a. In the orientation step of the problem, students were given a problem and asked to understand in order to determine the plan to resolve the problem.

b. In the organizing step, students discussed in groups to solve the problems presented in the discussion sheet.

c. At guiding individual/group investigations step, students were guided by the teacher in solving problems found in the discussion sheet.

d. At the step of developing and presenting the work, each group presented the results of the discussion in front of the class and the other group responded.

e. In the step of analyzing and evaluating the results of problem-solving, students reported the results of the discussion.

\section{Observing Stage}

The observation stage was carried out at the time of the implementation of the action. Observations were done by observers by filling out observation sheets. Moreover, the observers observed the learning process and students' learning activities.

\section{Reflecting Stage}

Teachers and collaborators analyzed and reflected on the implementation of the results of the actions in cycle I. The results of the analysis and reflection on the actions in the first cycle became the material for the implementation of the next action. After the second cycle ended, reflection was also carried out on the actions taken. The things found in cycle II have shown the expected results; therefore, the implementation action ended in cycle II. 


\section{Results and Discussion}

Learning mathematics at grade $\mathrm{V}$ has been carried out in accordance with the steps in Problem Based Learning. The findings showed that there was an improvement in students' active involvement, motivation and learning outcomes. The explanation is as follows;

\section{Students' active involvement}

Based on observations in cycles I and II, there has been an increase in students' active involvement. The average increases in cycles I and II are presented in the following diagram:

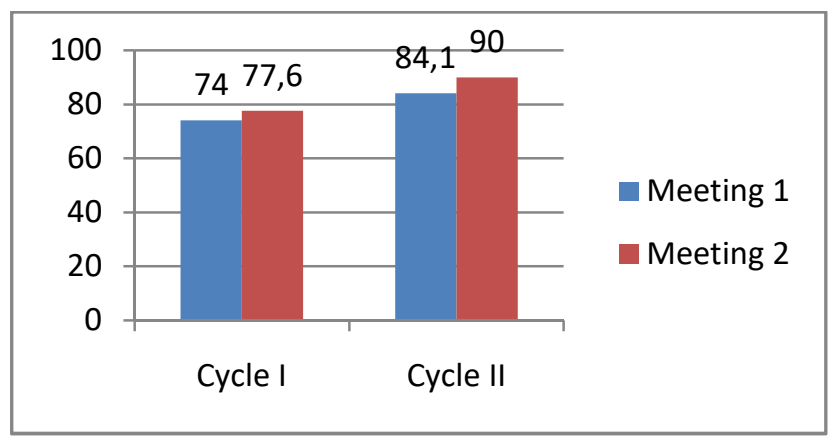

Figure 1 Average of Students' active involvement in each cycle

In the diagram above, there is an increase in the average of students' active involvement from cycles I and II. This increase means

a. The desire to read worksheets increased.

b. There was an emergence of critical and innovative attitudes of students in expressing ideas and opinions.

c. There were group discussions in answering problem-solving worksheets

d. There was sense of responsibility and enthusiasm in solving problems.

Based on the findings, it can be said that students' active involvements in math increased from cycle I to cycle II. This model was proven giving significant improvement in the way of thinking and reasoning in solving math problems. Learning activities will also increase if it is supported by a good classroom atmosphere (Hardianto, 2016).

\section{Students' Motivation}

Student learning motivation was measured using a motivational questionnaire. Motivational questionnaire was given at the beginning and end of the action in each meeting. There were 20 statements in the questionnaire which consisted of 10 statements of intrinsic motivation and 10 statements of extrinsic motivation.

The result can be observed in the following diagram 


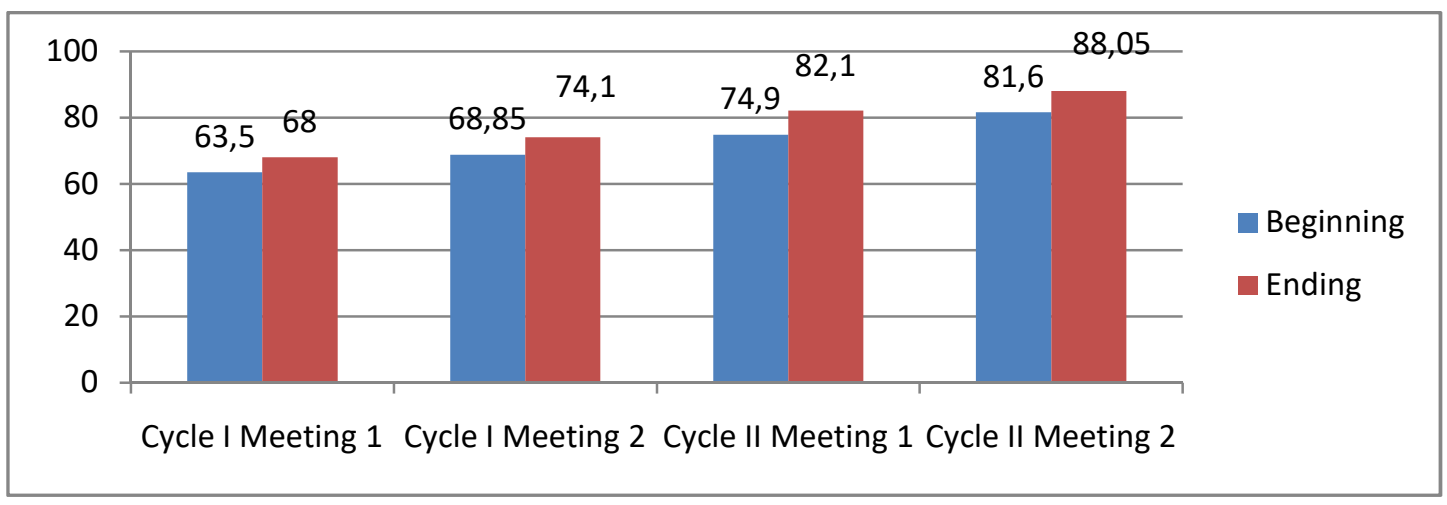

Figure 2. Results of Questionnaire on Student Learning Motivation

At the beginning of the first cycle, students' learning motivation towards mathematics was still low due to the fact that students did not like mathematics especially if it involved problem-solving. However, after the action or the end of cycle I, students' motivation was increasing.

At the end of cycle I, there has been an increase in students' motivation. Then, after the second cycle, it was getting higher. In the second cycle, students were more enthusiastic in learning. This was proven by courage that students showed when they expressed opinions in discussion and asked questions in learning. Furthermore, students have had confidence in reporting the result of discussion. Due to the increasing motivation, each student motivated themselvesnot only to learn, but also to have better understanding of the lesson (Hardianto, 2016).

\section{Learning outcomes}

Implementing Problem-Based Learning model has been able to improve problem-solving skills in mathematics. According to (Hardianto, 2016) students' learning outcomes can increase when students learn in a supportive situation. Moreover, (Hardianto, 2016) in his research stated that the increase in scores was simultaneously followed by the increase on students' learning outcomes. The learning outcomes can be seen from the students' score which were much higher. The details are presented in the following diagram.

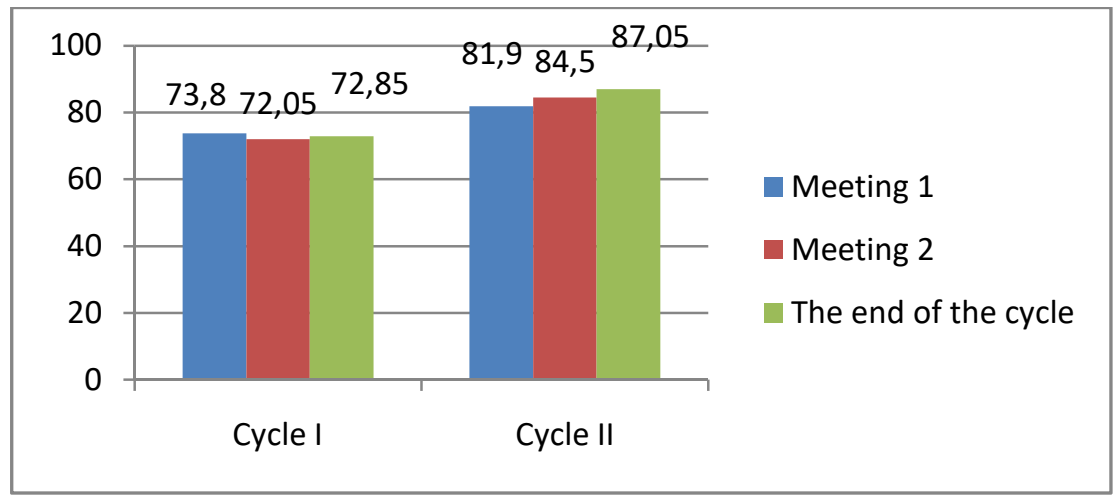

Figure 3. Students' learning outcomes

\section{Conclusions}

1. Students' active involvement has increased when they were taught using problem-based learning models at grade $\mathrm{V}$. It can be seen on the increasing average results of students' active involvement in learning activities from $76 \%$ in cycle I and $86.95 \%$ in cycle II. 
2. Students' learning motivation has increased as well. Students have been diligent in learning, resilient in facing difficulties, interested with the lesson, and excited to solve problems. The increase, which was $13 \%$, can be seen from the results of filling out questionnaires.

3. The average scores of students also increased from the end of the first cycle evaluation value which was72, $85 \%$ to $87.05 \%$ at the end of second cycle.

\section{Suggestions}

1. Teachers should use problem-based learning in teaching mathematics at grade $\mathrm{V}$ so that students' problem-solving skills can increase.

2. Implementing problem based learning in mathematics learning can enhance students' active involvement, motivation and student learning outcomes.

3. The use of PBL models should not only be used in math lesson especially KPK and FPB questions presented in the form of story, but it can also be is implemented in other subjects.

4. Schools, education offices and related parties should pay attention to the availability of learning facilities and infrastructure to enhance students' active involvement, motivation and learning outcomes.

\section{References}

Creswell, J. W. (2014). Penelitian kualitatif dan desain riset (A. Lazuardi, Trans.), Yogykakarta: Pustaka pelajar. (Naskah asli diterbitkan tahun 2013).

Amir, M. T. (2009). Inovasi Pendidikan Melalui Problem Based Learning. Jakarta: Kencana.

Arikunto, S. (2009). Penelitian Tindakan Kelas. Jakarta: Bumi Aksara.

Aunurrahman. (2009). Belajar dan Pembelajaran. Bandung: Alfabeta.

Hamalik, O. (2008). Proses Belajar Mengajar. Jakarta: Bumi Aksara.

Hardianto. (2016). Teori \& Pengembangan Iklim Kelas \& Iklim Sekolah. Jakarta: Kencana.

Karwati, E., \& Priansa, D. J. (2014). Manajemen Kelas. Bandung: Alfabeta.

Nuh, M. (2013). Menyambut Kurikulum 2013. Jakarta: Kompas.

Ronis, D. (2009). PBL for Math and Science. USA: SkyLight Professional Development.

Rusman. (2011). No TitleModel-model Pembelajaran Mengembangkan Profesional Guru. Jakarta: Rajawali Pers.

Sanjaya, W. (2008). Strategi Pembelajaran Berorientasi Standar Proses Pendidikan. Jakarta: Kencana Prenada Media Group. 